Kal|sgtos $\mid \begin{gathered}\text { Maio - Agosto } \\ 2018\end{gathered} \quad \begin{gathered}\text { Vol.15, N.2. } \\ \text { e-ISSN: 1984-9206 }\end{gathered}$

\title{
Ubuntu, Gender and Spirituality: Transformative Justice Considerations ${ }^{1}$ \\ [Ubuntu, gênero e espiritualidade: considerações de justiça transformativa]
}

\author{
Mechthild Nagel \\ Professor at State University of New York (SUNY Cortland), USA. \\ Center for Gender and Intercultural Studies (CGIS), SUNY Cortland, USA. \\ Research fellow with the Institute of Philosophy, Czech Academy of Sciences, Prague, Czech Republic. \\ E-mail: Mecke.Nagel@cortland.edu
}

\begin{abstract}
The Ubuntu principle, popularized by Archbishop Desmond Tutu presiding over the Truth and Reconciliation Commission in the New South Africa, has potential to assist Western philosophical conceptions of forgiveness in envisioning transformative justice. Aspects of Ubuntu overlap with the Western feminist inspired ethic of care while departing from Western ethics with its emphasis on spirituality and communalism.

Keywords

Gender. Transformative Justice. Ubuntu.

\section{Resumo}

O princípio do Ubuntu, popularizado pelo arcebispo Desmond Tutu, presidindo a Comissão de Verdade e Reconciliação na Nova África do Sul, tem potencial para auxiliar as concepções filosóficas ocidentais do perdão, na visão da justiça transformadora. Aspectos do Ubuntu se justapõem à ética do cuidado, inspirada pelas feministas ocidentais, ao mesmo tempo em que se afastam da ética ocidental, com sua ênfase na espiritualidade e no comunalismo.

Palavras-chave

Gênero. Justiça Transformativa. Ubuntu.
\end{abstract}

\footnotetext{
${ }^{1}$ Some parts of this paper draw on my article "An Ubuntu Ethic of Punishment," in The End of Prisons (Mechthild Nagel \& Anthony Nocella, eds.), Rodopi, 2013, pp. 177-186.

This publication is the outcome of the project "Performativity in Philosophy: Contexts, Methods, Implications. No. 16-00994Y; Czech Science Foundation" realised at the Institute of Philosophy of the Czech Academy of Sciences.
}

NAGEL, Mechthild. Ubuntu, Gender and Spirituality: Transformative Justice Considerations. p. 56-70. 
Western philosophy has had a complicated relationship with penality over its 2500year history. After all, a healthy suspicion of state ordered executions or other forms of punishment would have seemed understandable after the unjustified verdict of guilty launched against Socrates for his singular crime of corrupting the youth. Yet, instead the profession has defended with great zeal a systematic approach to punishment, including the extreme version of capital punishment. Sure enough, the focus has been on those who are truly guilty of the charges against them and thus either "deserve" punishment that is proportional to the crime or need to be punished so that they deter others from copycat actions. Finally, "doing time" within a prison seemed to fit a correctional ethos that would spur rehabilitation of the errant person in order to reenter society with rational prudential judgment. Today in the age of mass incarceration even as crime rates are falling, philosophers have to retrain ourselves to shed critical light on the lofty theories of retribution, deterrence, incapacitation, rehabilitation, and most recently reintegrative justice $^{2}$. This is a difficult task, since we got used to our approach of a systematic and unified theory of penality, which frankly has been very seductive and has clouded our vision. In the following, I offer something of a paradigm shift with an ethic of Ubuntu in order to help policy makers (and perhaps philosophers) understand that another path is more desirable, even if it looks utopian today and not terribly scientific or systematic. I am of course grateful to imprisoned intellectuals, to ICOPA, and Critical Resistance, who have guided my own thinking that is steeped in the tradition and language of Western philosophy and its myopia.

Ubuntu, this vexing principle describing interconnected humanity, literally turns Western (Cartesian) thought on its head with the maxim: "I am because we are, and because we are, I am," attributed to Kenyan theologian and philosopher John Mbiti (1969).

\footnotetext{
${ }^{2}$ Rosenthal et al. (2012) offer reintegrative justice as a new practice for judges to consider, i.e. that at the point of arrest, the offender's reentry options are being considered, along with ATI and the classical models of punishment. How might that work? Retribution, a backward-looking theory of punishment combined with reentry, a forward-looking theory that ought to assist with trimming down the prison population. It seems they are contradictory approaches and mired in the logical of classical penality: punish the individual and hope for the best when she is released to society. When judges, parole officers and social workers operate within the framework of retribution, not much good can come out these coercive institutions.
} 


\section{Kalsgatos}

Maio - Agosto

2018

Vol.15, N.2.

e-ISSN: 1984-9206

When put together with respect to penality, it signals a justice system that is quite at odds with Western ideology. African justice systems tend to be forward-looking (not retributivist); process-oriented with the goal of restoring relationships and social harmony, thus healing the community from harm; cognizant that harm is an offense against human relationships; partial yet fair-minded, where elders or jeliw (griot/griottes) who know the offending and victimized parties intervene swiftly; cooperative and consensus-driven such that results may involve compensation-not simply restitution (cf. Elechi, 2004; Nagel, 2008). Elechi tellingly notes: "African indigenous justice systems see crime not just as a violation of people and relationships, but also as an opportunity for transformative healing for all vicitim(s), offender(s), family members, friends, witnesses and members of the community" (p. 158). Where it works well, namely as a healing process, women are also empowered to participate, often in their age-mate specific women-only councils, or, at least, they have considerable influence in the male gerontocratic councils (Elechi, pp. 165-171).

Why Ubuntu? I attended a conference around 2000 with the theme "What good can come out of prison?" and the conference highlighted the contributions of exprisoners who achieved the elusive goal that the Quakers dreamed of-bettering themselves through writing and painting behind walls. Prisoners are usually the last folks consulted when paid experts opine about theories of punishment. The students behind walls that I had the pleasure of getting to know in my philosophy courses were eager to show me intellectual and spiritual connections that I had never thought of. Some asked what I thought of Steve Biko—I had never heard of him before entering prisons. Many students cherished a Afrocentric worldview which had a tremendous effect on me-hearing from them evocative comparisons of the slavery of prisons with the prison of slavery, as another exprisoner, Angela $Y$ Davis, put it so well. Later, in my literal and literary travels throughout the African continent, I have found that there is much good that we (in the West and Global North) can learn from African indigenous, traditional practices in our search for transformative justice.

In the ethic of Ubuntu I find this yearning that I see refracted in the Black and Latino students, namely the yearning for getting along and for belonging to the beloved community. Breaking the psychic and material walls of the carceral is one first and important step in this process of revisioning punishment. Furthermore, aspects of Ubuntu

NAGEL, Mechthild. Ubuntu, Gender and Spirituality: Transformative Justice Considerations. p. 56-70. 


\section{Kalsgatos}

Maio - Agosto

2018

Vol.15, N.2.

e-ISSN: $1984-9206$

overlap with the Western feminist inspired ethic of care (Gilligan, 1982). Finally, by supporting Ubuntu, I am also beholden to its spiritual message, which is missing in Western ethics in toto, and I readily admit that supporting it will undermine a scientific philosophical assessment.

To begin with the last point-in the Apology Socrates readily admits to a spiritual foundation of his defense and plea to the Athenians to let him go. He talks about the Delphi oracle (which declares him the wisest of all Athenians) and about a peculiar inner voice, the daimonion (easily mistranslated as demon) that guides his ethical behavior. "This sign I have had ever since I was a child. The sign is a voice which comes to me and always forbids me to do something which I am going to do, but never commands me to do anything..." (Plato, Apology of Socrates). In the Phaedrus, Socrates calls it divine madness, i.e. the demonic is a sign from God. It's easy enough to diminish this spiritually driven intuitive guidance and "rationalize" it away, so to speak, so that it becomes simply the "voice of Reason" or conscience that forbids transgressions. The daimonion only appears where Reason (logos) fails Socrates' judgment (Gundert, 1977, p. 50). So,

philosophers such as Gundert have carved out a very limited space for the daimonion, as delineated in the Apology-it appears when it warns Socrates against participation in political life and when it supports a "benediction of his death" in front of the jury of 500 (ibid). Of course, here as penal abolitionists, we might pay attention that the spiritual emphasis comes to the fore in all matters of life and death, even in the courtroom! Philosopher Greg Moses who has shared my passion for teaching in prisons puts it all together in the following "maxim": prisons are the material condition for becoming spiritual. Here, for me, prisons become shorthand for the entire criminal justice system.

It seems odd that philosophy since Aristotle committed a secular turn-but such is the revolt of the youth against their teachers (i.e. Plato). All of the classical theories of punishment or the defense of the prison have something "mechanical" about them: there's a rational foundation of criminality, today the latest fad explores bio-chemical causes, as neuroscience has developed new standards with respect to executive function theories, frontal lobe measurements, and other positivistic machinations-all quite fascinating and seemingly helpful in guiding our confused horror and abjection of the truly bad (or evil) criminal.

NAGEL, Mechthild. Ubuntu, Gender and Spirituality: Transformative Justice Considerations. p. 56-70. 
The ancient Greek worldview is also steeped in considering all life in an organic whole. An example of architecture: the amphitheatres at the sacred sites of the Akropolis or in Delphi are carved into the mountain, rather than being erected on a plane such as the massive Roman Colosseum. This emphasis of holism becomes important for making links to other than European traditions. Across indigenous cultures that have remained with precolonial judicial customs, peculiarly labeled as customary law, which could easily be said of the British system of "case law," there is an emphasis on the effects of harm that involves everybody affected. It is not harm done against the crown or the abstract state, adjudicated by its prosecutor and judge.

I maintain that the most promising aspect of Ubuntu is that it can serve as a powerful antidote to traditional Western punishment theories. Thaddeus Metz (2010) outlines that Africans tend to resort to forward-looking rationales for punishment, for spiritual and practical reasons (p. 325). An Ubuntu ethic of punishment favors restitution over revenge. This is what Desmond Tutu strategically deployed in the Truth and Reconciliation Commission (TRC), when he admonished victims and survivors of apartheid violence to forgive as well as excoriated offenders to deliver genuine, credible apologies for their deeds of atrocity and crimes against humanity. It is worth quoting Archbishop Tutu's explanation of Ubuntu in toto, because it shows how he Christianizes the concept to speak to a global audience that may not understand ancestor worship (as explained in Louw, 1998). He makes the connection with Christian morality by appealing to agape, reciprocity, and shared suffering:

\begin{abstract}
[Ubuntu] is the essence of being human. It speaks of the fact that my humanity is caught up and is inextricably bound up in yours. I am human because I belong. It speaks about wholeness, it speaks about compassion. A person with ubuntu is welcoming, hospitable, warm and generous, willing to share. Such people are open and available to others, willing to be vulnerable, affirming of others, do not feel threatened that others are able and good, for they have a proper self-assurance that comes from knowing that they belong in a greater whole. They know that they are diminished when others are humiliated, diminished when others are oppressed, diminished when others are treated as if they were less than who they are. The quality of ubuntu gives people resilience, enabling them to survive and emerge still human despite all efforts to dehumanise them (Tutu, 1999).
\end{abstract}

If it is the case that my humanity is connected to another person (for example, an offender), then I have a bit of cruelty, sadism, lack of love in me as well, and as such I can 


\section{Kalsgatos}

Maio - Agosto

2018

Vol.15, N.2.

e-ISSN: 1984-9206

relate to the action of the offender/oppressor. Radically put, I (as a victim) am also responsible for the ghastly deed of the oppressor. However, such heightened level of responsibility sits uneasily with a Western philosophical audience, steeped in notions of individual culpability. John Braithwaite claims that asking victims to forgive, or offenders to apologize, is wrong, if not cruel. Forgiveness and apology "are gifts that have no power as gifts when they are demanded" and they only play a role in restorative justice as "emerging values" that might arise out of the process (2011, p. 349). Tutu's overreach then may consist in making these values into "constraining values" that have to be part of any successful restorative process, (that is, ground rules of conduct). Braithwaite, on the other hand, claims that constraining values deal with respectful listening, non-domination, empowerment, equal concern for all stakeholders, and freedom from racist and sexist oppression, appealability and accountability (ibid., p. 348). Tutu would, in all likelihood agree to these ground rules, and the TRC Commission mixed indigenous principles with Western rule of law, since the TRC referred those who didn't win amnesty to criminal court. The TRC was the first commission of its kind for letting victims, victims' families and offenders speak, as well as offering psychological counseling to those who were deeply traumatized by recounting past events. However, many critics of the TRC note that it was a "Truth" commission, rather than one of reconciliation, since, despite Tutu's strenuous efforts, victims often did not sense that justice was served and that offenders apologized in a lighthearted way in order to receive the coveted amnesty. Furthermore, as Tutu (1999) acknowledges, the whole process was undermined by the government's delay of reparations to bona fide victims and victims' families.

Some critics of the TRC proceedings would probably agree with critics of restorative justice, who hold that a fanatical focus on the restorative "process" may actually yield injustice (for the victim and/or her community). In order for restorative processes to work in consort with "doing justice," certain sentencing guidelines have to be met that are shared by the larger community, (that is, the rule of law and codification of criminal offenses, Robinson, 2011). "Doing justice" then amounts to "just punishment" of the offender, even if it goes contrary to the wishes of the victim. Hence, the principle of appealability comes to play here, since any consensual agreements arrived at by both parties in a, say, sentencing circle, which includes community members of both offender and victim, can then be appealed by a state actor, for example a district attorney, to the 
conventional criminal court system. A much-quoted case study from New Zealand illuminates the trouble of interweaving mediation or community justice with criminal courts. In this case, the victim, Patrick Dale Clotworthy, survived a violent assault, leaving him with a scar that needed cosmetic surgery repair, which the offender was willing to pay for in addition to community service. The Court of Appeal reduced the payment, which then made surgery impossible, and instead argued from the principle of deterrence, interning the defendant for four years. Subsequently, Clotworthy committed suicide, "for reasons unknown" (cf. Braithwaite, 2011, p. 347). I argue that appealing community justice or sentencing circles' decisions to an adversarial criminal justice system fundamentally violates the ethic of Ubuntu, as the trust between the parties is broken and dissent is the final outcome. The underlying principle of appealability is based on abstract rights, individualism, and retribution that goes against the ideas of compassion (Tutu, 1999), power sharing (Louw, 2002) and interconnectedness with those who are living-dead (the ancestors) and the yet-to-be-born (Ramose, 2003). In pre-colonial times, African jurisprudence focused on restoring (divine) order in the human community after a crime was committed and a decision had to be made to appease both the living and spiritual realm beings (cf. Achebe, 1958). In some African cultures, it may have involved gift-giving and apologies by both parties (the offending and the aggrieved) with the outcome that future generations of their families could be intermarried and live harmoniously. Such practices of Ubuntu are still used across the South of the Sahel (cf. Nagel, 2007; Murithi, 2005).

The Western rule of law in democratic theory takes a keen interest in human rights, in the abstract rights of the individual. Ubuntu also allows for individuality in balance with concern for the community. This is of particular interest to citizens in the New South Africa, as the following makes clear:

The Ubuntu respect for the particularities of the beliefs and practices of others (cf. also Wiredu, 1995), is especially emphasized by a striking, yet (to my mind) lesserknown translation of umuntu ngumuntu ngabantu: "A human being is a human being through (the otherness of) other human beings" (Van der Merwe, 1996:1, italics mine). For post-apartheid South Africans of all colors, creeds and cultures, Ubuntu demands that, if we were to be human, we need to recognize the genuine otherness of our fellow citizens (Louw, 1998).

How do we recognize the individual in her particularity? Louw offers playfully this (African) solution:

NAGEL, Mechthild. Ubuntu, Gender and Spirituality: Transformative Justice Considerations. p. 56-70. 
This is all somewhat boggling for the Cartesian mind, whose conception of individuality now has to move from solitary to solidarity, from independence to interdependence, from individuality vis-à-vis community to individuality à la community' (ibid.).

In other words, individualism cannot trump communalism, and lest there would be a celebration of communal dictate over individual rights and ontology, Ubuntu holds in balance both as co-equal and as such giving rise to a full expression of the diversity of humaneness. So, it may not be the solipsistic Cartesian or Kantian ego that we find reflected in Ubuntu metaphysics, but rather a version of Hegelian intersubjectivity. ${ }^{3}$

Given what we know of the normative tenets of an Ubuntu ethic, what would be the ramifications for a postcolonial theory of such an ethic, in particular vis-à-vis the concept of punishment? Is it an ideal theory that is disconnected from social context, much as a Rawlsian theory of justice has been described by feminist theorists (cf. Jaggar, 2009)? The answer is complicated. On the one hand, Desmond Tutu's prophetic fervor and zeal is seductively simple and appealing to the kernel of love in each of us. On the other hand feminists contest such sentiment by noting that men have excused male chauvinist behavior under the cover of Ubuntu in order to pressure women to respond compassionately. Thus, a non-ideal theory of an Ubuntu ethic of punishment would have to stay clear of romanticism and wishful disappearance of racist, ethnocentric, sexist, and homophobic realities in the postcolonial polity. And perhaps we have to say with Braithwaite that some values are aspirational, or emerge out of the restorative justice process. However, here I question, also, the concept of "restorative justice." In a non-ideal world, the status quo ante is not simply harmonious; the violence of poverty, racism, and sexism all impact our lives, albeit in differentiated ways within the matrix of domination. Abolitionist penal theory tends to frame the "justice project" in terms of transformational

\footnotetext{
3 Here I will make note of the controversial, yet exciting, findings of Susan Buck-Morss (2000) in her essay on "Hegel and Haiti." The trope of the master-slave dialectic is indebted to Hegel's reflections on the Haitian revolution (1791-1804), which was a unique world event in that it freed Haiti both from slavery and colonialism at once. I mention her discovery, since it's well known that Hegel disparaged Africa for being devoid of history and for that matter, human ingenuity and agency; yet he was sufficiently inspired by the Haitian revolution to make light of it (by erasing the historical event) in the deadly dance of recognition between "master" and "slave" in his masterwork of the Phenomenology of Spirit (1807), which he completed in 1806 .
}

NAGEL, Mechthild. Ubuntu, Gender and Spirituality: Transformative Justice Considerations. p. 56-70. 


\section{Kalsgatos}

Maio - Agosto

2018

Vol.15, N.2.

e-ISSN: $1984-9206$

considerations (Davis, 2005). How does this work with respect to Ubuntu? When a personal crime is committed, the community gets together along with the offender (also a troubled term according to transformative justice analysis) and the victim and, of course, the ancestors. The process may involve ritual ceremonies and prayers, and the focus will be on an outcome that will be arrived at through consensual, respectful listening and speaking. Space does not allow for an extensive discussion of comparing Ubuntu ethic with Plato's moral theory of punishment (cf. Mackenzie, 1981). However, let me briefly note that there are interesting similarities that derive from an organic worldview that focuses on the harmony of the polis/community, and even though Plato does not articulate it as such, except through the tri-partite structure of the soul, if one person breaks a law, the entire group/polis will be seen as lawbreakers, and all have to commit to solve the conflict to restore cosmos/order (Murithi, 2006).

Indigenous societies all share the aspect of Ubuntu that emphasizes interconnection, not only in the anthropocentric way, but with respect to all there is. Punishment might just be an alien concept among peaceful societies. One practice is the spiritually based Hawai'ian principle of Ho'oponopono: becoming really whole, reestablishing divine harmony within oneself. It is the realization that as long as there is "evil" in the world, there is some aspect in myself that has that potentiality of doing evil, therefore I am also responsible for co-creating it. This system has no need for organized religion, teachers, conduits, but invites everybody to take part in it without any hint of coercion. There are four sentences that articulate the wisdom of Ho'oponopono: "I am sorry. Please forgive me. I love you. Thank you." This simple mantra was followed by medical doctor Ihaleakala Hew Len who reviewed the files of his patients in a closed mental health unit in a prison for over a year, before even talking to any one of them. He meditated on each offense and challenge looking inwardly, where he had a similar challenge and was responsible for the other's transgression. After a year of going through this process of silent review and meditation, the atmosphere had so vastly improved that the prisoners were no longer handcuffed, and within a few years of talking with them, the entire unit had to be closed in 1987-all but two of the 30 "criminally insane" patients were healed-and then again, Dr. Len insists that he only worked on his own healing, not that of his patients (Vogt, 2012).

NAGEL, Mechthild. Ubuntu, Gender and Spirituality: Transformative Justice Considerations. p. 56-70. 


\section{Ubuntu and Feminist Considerations}

One of the most fervent critiques of Ubuntuism comes from feminist scholar Fainos Mangena (2009). He calls attention to a masculinist ethos in Ubuntu, which he finds particularly worrisome in the age of HIV/AIDS, which has had a devastating impact on many African countries. African women are told by community elders to take care of a husband who has HIV/AIDS by extolling the spirit of Ubuntu (or Hunhu, in Shona). If Ubuntu is not the answer and salvation for "the" African woman, what about an ethic of care that has captured Western feminist's imagination ever since Carol Gilligan popularized it with her study of girls and boys' different sense of morality with her article (later turned into a book) "In a Different Voice: Women's Conceptions of Self and Morality" (1977)?

The ethic of care developed out of a need to differentiate girls' experiences in their moral socialization from that of boys. Gilligan suggests that boys are tasked to follow an ethic dominated by (public) sphere concerns of impartiality and justice, which is made most plainly in the deontological version of the categorical imperative. Girls on the other hand have a (private) sphere concern for partiality and they may justify theft of a necessary medication to keep a sick family member alive. Clearly, their justification doesn't meet the basic demands of the categorical imperative (that is, that theft can never be considered a universalizable maxim).

One of the criticisms Gilligan incurred was that her study was one of white middle class women. Mangena notes that her ethic of care may be fitting for a Western (white) possessive individualist ethical framework, but it carries very little weight in a society where the community comes first and the needs and the desires of the individual are quite secondary - and especially frowned upon when uttered by a (married) woman. "So, for the Western woman, it is a question of saying: What form should a care-giving ethic take? While for the African woman the question is: What am I expected to do by my culture" (Mangena, 2009, p. 24). However, following Gilligan, other feminists, notably Nancy Chodorow (1978), have articulated a relational theory of the self that girls are acculturated, if not pressured, to adopt, whereas boys are steered toward an autonomous sense of self.

NAGEL, Mechthild. Ubuntu, Gender and Spirituality: Transformative Justice Considerations. p. 56-70. 
So, women, especially qua mothers and daughters of elderly parents, are summoned to be compassionate in order to meet society's approval in the West. Such patriarchal expectations of women seem mirrored in the African concept of Ubuntu where hospitality toward strangers, compassion, magnanimity, and certainly care for the other is part and parcel of expressing of one's humanity. On the other hand, African men's sense of irresponsibility as painted by Mangena (for example, engaging in risky behavior) mirrors any patriarchal society's Anspruch (in the global North as well as South) to individual freedom and autonomous expressions. (I leave aside some of the disturbing conclusions of the author, including a eugenic sounding wish for the disappearance of African patriarchal men due to AIDS, p. 27.) My criticism of Mangena's ethic mirrors my concern about Metz's version: Mangena's description of an African feminist ethic is clearly based upon the liberal Anglo-American human rights agenda (for example, by suggesting that women should have a public voice and influence policy decisions, whether and under what circumstances they want to be caregivers to men living with HIV/AIDS). Thus, I am unsure what else (maybe virtues? another set of principles?) he brings to a normative discourse. His critical intervention on Ubuntu is however useful to get us to look into the challenge of avoiding a romantic perspective on Ubuntu. Is it descriptive or normative, that is, of aspirational value? Ann Outwater and others suggests something of both:

\footnotetext{
It has been suggested that the transformation of an apartheid South Africa into a democracy is a rediscovery of ubuntu (Maphisa, cited in Loew, 2003). Ubuntu is a given and a task in African societies. It is part and parcel of Africa's cultural heritage. However, it clearly needs to be revitalized in the hearts and minds of some Africans (Koka, 1997; Shutte, 1993; Teffo, 1994). The actions suggested in the literature are part of this renaissance (Outwater et al., 2005, p. 147).
}

The Nguni saying of "a human is only human through other humans" (umuntu ngumuntu ngabantu), which encapsulates the Ubuntu spirit, does not betray gender bias. Yet, some feminists find in it an expression of brotherhood. After all, as Gade's (2011) catalogue of Ubuntu genealogy shows, one of the early explanations of Ubuntu refers to "manly virtue." Historically speaking, many pre-colonial African societies were not only patrilocal and patrilineal, but their customs certainly had and continue to have patriarchal tendencies with precarious consequences. Female Genital Circumcision (FGC) is one the most infamous practices mentioned at international forums, because young girls are not 
able to give consent to such procedures. An engaging African pro-feminist critique of FGC is portrayed in Ousman Sembène's film Moolaadé (2004) where the protagonist who offers magical protection (moolaadé) to uncircumcised girls is punished by her own husband for doing so, being whipped so severely that she could have been killed. Then in a turn of fortune, she returns to the village center quite victoriously with a band of women who defy patriarchal elders and accuse them of a misreading of the Qu'ran-which does not condone FGC.

Certainly, discovering one's humanity through other persons seems to be germane to all indigenous pre-colonial value systems. Yet Ubuntu tends to have a more anthropocentric connotation than others. Humans are entrusted to act as stewarts over the earth and non-human animals, yet it presumes a disruption of spiritual inter-connection to the crawling ones, the stone people, the wind, the fire, the water, and importantly the earth-to put it in the language of American Indian peoples. Still, as Dirk Louw (1998) notes, African humanism is imbued with deeply religious/spiritual meaning, which is difficult to retrieve for Western secular value systems and institutional practices:

For the Westerner, the maxim 'A person is a person through other persons' has no obvious religious connotations. He/she will probably interpret it as nothing but a general appeal to treat others with respect and decency. However, in African tradition this maxim has a deeply religious meaning. The person one is to become 'through other persons' is, ultimately, an ancestor. And, by the same token, these 'other persons' include ancestors. Ancestors are extended family. Dying is an ultimate homecoming. Not only the living must therefore share with and care for each other, but the living and the dead depend on each other (Van Niekerk, 1994:2; Ndaba, 1994:13-14).

Can Ubuntu engender a feminist ethic? One way it certainly can is to postulate that "manly virtue" is a deliberate or unconscious biased misapplication of the concept that seems so foundational to what counts as African philosophy (cf. Ramose, 2003). It may be problematic to venture into ideal theory, yet if one attends to roots of a concept, it seems to me important to provide a corrective to an ideologically convenient retrieval of a concept that demands submission of women to a masculinist ethos. Of course, it is disconcerting that African women philosophers' voices are missing in this debate (cf. Presbey, 1998). To some African feminists Tutu's championship of Ubuntu has been linked to the nationbuilding project (a new South Africa) and such patriotic calls may have paternal/patriarchal undertones (Patricia McFadden, personal communication, 2011). They are accentuated 


\section{Kalsgatos}

Maio - Agosto

2018

when women's critique of patriarchal or outright misogynist customary practices are asked to step back with their claims in favor of healing the nation. The South African constitution seems to have got it right by acknowledging customary rights where it doesn't contravene human rights demands. However, how to balance cultural communal practices with individual civil rights continues to preoccupy feminist postcolonial theorists and advocates.

Ubuntu-based justice that follows the transformational paradigm (Morris, 1995) advocates for broader goals of justice, other than adjudicating conflicts, which would include demands for dismantling power structures in all institutions of society-and beyond: international institutional bodies. This indeed might be an ideal worth striving for (peacefully) and would spell the end of punishment.

\section{REFERENCES}

Achebe, Chinua. 1958. Things fall apart. Oxford: Heinemann.

Braithwaite, John. 2011. In Search of Restorative Jurisprudence. Why punish? How Much? A Reader on Punishment (M. Tonry, Ed.), 337-352. New York: Oxford University Press.

Buck-Morss, Susan. Summer, 2000. Hegel and Haiti. Critical Inquiry, 26(4): 821-865.

Chodorow, Nancy. 1978. The Reproduction of Mothering: Psychoanalysis and the Sociology of Gender. Berkeley \& Los Angeles: The University of California Press.

Davis, Angela Y. 2005. Abolition Democracy: Beyond Empire, Prisons, and Torture. New York: Seven Stories Press.

Elechi, Ogbonnaya Oko. 2004. Women and (African) Indigenous Justice Systems. PanAfrican Issues in Crime and Justice (ed. Anita Kalunta-Crumpton \& Biko Agozino, Eds.), pp. 157-178. Aldershot, UK: Ashgate.

Gade, Christian B.N. 2011. The Historical Development of the Written Discourses on Ubuntu' South African Journal of Philosophy, 30(3): 303-329.

Gilligan, Carol. (1977). In a Different Voice: Women's Conceptions of Self and Morality. Harvard Educational Review 47(4): 481-517.

Gundert, Hermann. 1977. Platon und das Daimonion des Sokrates. Platonstudien. John Benjamins Publishing Co.

Jaggar, Alison. 2009. L'imagination au pouvoir: Comparing John Rawls's Method of Ideal Theory with Iris Marion Young's Method of Critical Theory. Dancing with Iris: The

NAGEL, Mechthild. Ubuntu, Gender and Spirituality: Transformative Justice Considerations. p. 56-70. 


\section{Kalsgatos}

Maio - Agosto

2018

Philosophy of Iris Marion Young (Ann Ferguson and Mechthild Nagel, Eds.), pp. 95101. New York: Oxford University Press.

Louw, Dirk J. (2002). Power Sharing and the Challenge of Ubuntu Ethics.

uir.unisa.ac.za

Louw, Dirk J. (1998). Ubuntu: An African Assessment of the Religious Other. Symposium:

Philosophy in Africa. Paideia. http://www.bu.edu/wcp/Papers/Afri/AfriLouw.htm

Mackenzie, Mary Margaret. (1981). Plato on Punishment. Berkeley \& Los Angeles: University of California Press.

Mangena, Fainos. (2009). The Search for an African Feminist Ethic: A Zimbabwean Perspective. Journal of International Women's Studies, 11(2): 18-30.

Mbiti, John. 1969. African Religions and Philosophy. London: Heinemann.

Metz, Thaddeus. 2010. Toward an African Moral Theory. The Journal of Political Philosophy, 15(3): 321-341.

Morris, Ruth. 1995. Penal Abolition: The Practical Choice. Toronto: Canadian Scholars' Press.

Murithi, Timothy. (June, 2006). Practical Peacemaking Wisdom from Africa: Reflections on Ubuntu. The Journal of Pan African Studies, 1(4).

http://www.jpanafrican.com/archive issues/june2006vol1no4.htm

Nagel, Mechthild. 2008. What if Habermas Went Native?" Peace Studies Journal, 1: 1-12. http://www.peacestudiesjournal.org/archive/Nagel.pdf

Nagel, Mechthild. 2007. Gender, Incarceration and Peacemaking: Lessons from Germany and Mali. Prisons and Punishment: Reconsidering Global Penality (M. Nagel \& Seth Asumah, Eds.), pp. 43-51. Trenton, NJ: Africa World Press.

Outwater, Anne, Naeema Abrahams and Jacquelyn C. Campbell. (2005). 'Women in South Africa: Intentional violence and HIV/AIDS: Intersections and prevention.' Journal of Black Studies, 35: 135-154.

Plato. Apology of Socrates, trans. Benjamin Jowett.

Plato. Phaedrus.

Presbey, Gail. (1998). 'Who counts as a sage? Problems in the further implementation of sage philosophy.' Symposium: Philosophy in Africa. Paideia.

http://www.bu.edu/wcp/Papers/Afri/AfriPres.htm

NAGEL, Mechthild. Ubuntu, Gender and Spirituality: Transformative Justice Considerations. p. 56-70. 
Ramose, Mogobe B. (2003). 'The philosophy of ubuntu and ubuntu as a philosophy.' The African philosophy reader: $A$ text with readings, $2^{\text {nd }}$ ed. (P.H. Coetzee \& A.P.J. Roux, Eds.), pp. 230-238. New York: Routledge.

Robinson, Paul H. (2011). 'The virtues of restorative processes, the vices of "restorative justice." Why punish? How much? A reader on punishment (M. Tonry, Ed.), 353-366. New York: Oxford University Press.

Rosenthal, Alan, Marsha Weissman, and Elaine Wolf. 2012. Unlocking the Potential of Reentry through Reintegrative Justice. Pathways for Offender Reentry: An ACA Reader (Russ Immarigeon \& Larry Fehr, Eds.). ACA. (online)

Tutu, Desmond. 1999. No Future without Forgiveness.

Van der Merwe, 1996.

Vogt, Michael. (2012). Hooponopono-Blockaden lösen. http://heile-deinherz.de/hooponopono/

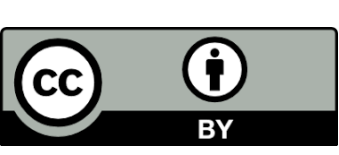

